\title{
Promotion of Innovation and S\&T: The Role of Finance
}

\author{
Saeed Ahmed and Mahmood ul Hasan Khan*
}

\begin{abstract}
Promotion of innovation and SET enables economies to achieve sustainable economic growth. In addition, firms engaged in medium- to high-tech production tend to gain more from innovation and are, on average, more productive compared to enterprises which are limited to low-tech systems. Innovation is, in turn, inextricably linked to the availability and nature of financing. Empirical studies in developing countries reveal that bank financing and FDI can play a vital role in this regard. This paper provides an overview of: (a) the role of financing in facilitating innovation and SET; (b) State Bank of Pakistan's policy initiatives to make financing available, both in general, and also to specifically facilitate innovation and SET in the country; and (c) the role of innovations in expanding access to finance in Pakistan.
\end{abstract}

Keywords: Technological innovation, R\&D, policy, banks

JEL classification: E61, O32, G21.

\section{Introduction}

The role of innovation and S\&T can hardly be over emphasized for sustainable economic growth. Paul Romer, an economist and policy entrepreneur, has aptly used the kitchen metaphor to describe innovations and production in an economy. "The cooking one can do is limited by the supply of ingredients... If economic growth could be achieved only by doing more and more of the same kind of cooking, we would eventually run out of raw materials... History teaches us, that economic growth springs from better recipes, not just from more cooking... Every generation has underestimated the potential for finding new recipes and ideas. We consistently fail to grasp how many ideas remain to be discovered. Possibilities do not add up. They multiply."

\footnotetext{
* The authors are Chief Economic Advisor (Dr.Ahmed@sbp.org.pk) and Additional Director (mahmood.khan@sbp.org.pk), State Bank of Pakistan (SBP), respectively. The views expressed in this paper are those of the authors and not necessarily of the State Bank of Pakistan. We would like to thanks Mr. Talha Nadeem for his excellent research assistance.
} 
It is well documented in the literature that innovative firms are more productive than non-innovating counterparts. Moreover, the firms in lessdeveloped countries tend to experience greater productivity gains from innovation compared to developed country peers; innovation in the latter occurs at the technology frontier, and might involve both hits and misses of previously untested products and processes (Dabla-Norris et al, 2010).

More often than not, a country's propensity to innovate is not a chance event; rather, it is an outcome of conscious policy decisions. Specifically, the polices towards education, $R \& D$, intellectual property rights, contract enforcement, creditors' rights, availability of external funding, etc., create an enabling environment to promote innovations and S\&T. Policymakers, however, face tough choices when making allocation decisions about expenditures on $R \& D$, health, education, infrastructure, defense and other priority areas. While, in principle, few policymakers (if any) would suggest that public expenditure on R\&D is devoid of merit, such spending may be constrained by fiscal limitations.

On the one hand, the role of traditional finance merits discussion in the context of innovation and S\&T, since availability of financing is a vital enabling factor leading to increased firm innovation. Ayyagari et al (2012) argued that bank financing is a vital source of external financing which leads to innovation, and is particularly relevant for SMEs in developing countries. On the other hand, if traditional financing modes are insufficient, the discussion may be expanded to alternative forms of financing which can play a complimentary role, such as venture capital from private actors. In these settings, this paper provides an overview of: (a) the role of financing in facilitating innovation and S\&T in case of Pakistan; (b) State Bank of Pakistan's policy initiatives to make financing available, both in general, and also to specifically for targeted sector; and (c) the role of innovations in expanding access to finance in Pakistan.

The remainder of this paper proceeds as follows: Section I provides some background on innovation in a global context; Section II discusses the role of financing in facilitating S\&T and innovation; Section III highlights SBP's policy initiatives to make financing available, both in general, and also to specifically facilitate $S \& T$ and innovation in the country; Section IV outlines the role of innovations in expanding access to finance in Pakistan; and finally, the last section offers concluding remarks. 


\section{Section I. Global background- Where do we stand?}

The Global Innovation Index (GII) 2015, which ranks innovation performance of 141 countries, reveals that India is the most innovative economy in the Central and South Asian region, whereas Singapore is the top ranked within Southeast Asia. Global rankings of interest include: Singapore (7), China (29), India (81), Bangladesh (129), and Pakistan (131) (Figure 1). Incidentally, China and India are among the countries identified as "innovation achievers" - those who "perform at least 10 percent better than their peers for their level of Gross Domestic Product". Moreover, the GII places India and Pakistan in the same peer group (along with Sri Lanka, Bhutan and Uzbekistan), which makes India a relevant country for comparison by Pakistani policymakers and academics.

\section{Figure 1: Global Innovation Index}

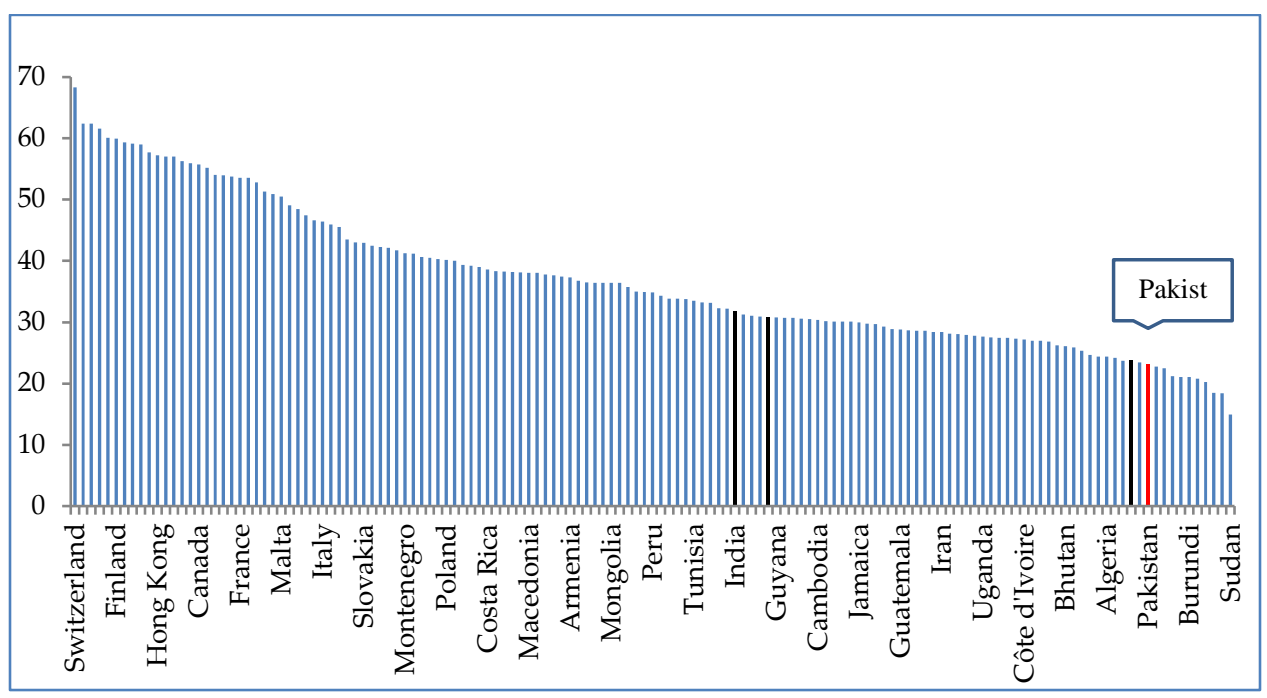

To understand where the country is really lagging behind compared to its peers, we need to analyze the subcomponents of the GII. ${ }^{1}$ Table 1 highlights Pakistan's comparative ranking on selected indicators. Referring to rankings from Table 1, political stability and security concerns, on which Pakistan ranks the lowest, add to uncertainty among investors and other stakeholders. Additionally, the country's rank on school life expectancy, which reflects the years of schooling that a child can

\footnotetext{
${ }^{1}$ The index comprises seven broad pillars - institutions, human capital and research, infrastructure, market sophistication, business sophistication, knowledge and technology outputs, and creative inputs - which together represent 79 specific indicators.
} 
expect to receive, is also a weak link: Pakistan's $128^{\text {th }}$ ranking places it 33 spots behind India and 63 spots behind Sri Lanka.

Table 1: Ranking on select GII 2015 indicators

\begin{tabular}{lcccc}
\hline & Pakistan & Bangladesh & India & Sri Lanka \\
\hline $\begin{array}{l}\text { Political stability \& absence of } \\
\text { violence/terrorism index }\end{array}$ & 141 & 134 & 124 & 101 \\
School life expectancy (years) & 128 & 116 & 95 & 65 \\
Gross capital formation \% of GDP & 130 & 24 & 14 & 15 \\
Firms offering formal training, \% firms & 107 & 87 & 98 & 94 \\
New business density & 104 & 101 & 99 & 88 \\
(registrations/thousand population 15- & & & & \\
64 years old) & 48 & 40 & 25 & 55 \\
Total value of stocks traded, \% GDP & 34 & 121 & 1 & 12 \\
Communications, computer \& & & & & \\
information services exports, \% total & 21 & 41 & 7 & 49 \\
trade & & & & \\
Ease of protecting investors & & & & \\
\hline
\end{tabular}

Source: Global Innovation Index 2015

The gross capital formation indicator presents the starkest contrast among ranking for Pakistan (130), Bangladesh (24), India (14) and Sri Lanka (15). It implies that low level of investment is acting as a major constraint to innovation and growth in Pakistan's economy. This finding is further corroborated if we view a plot of gross fixed capital formation in the private sector for India and Pakistan over time (Figure 2).

Figure 2: Gross fixed capital formation in the private sector (\% of GDP)

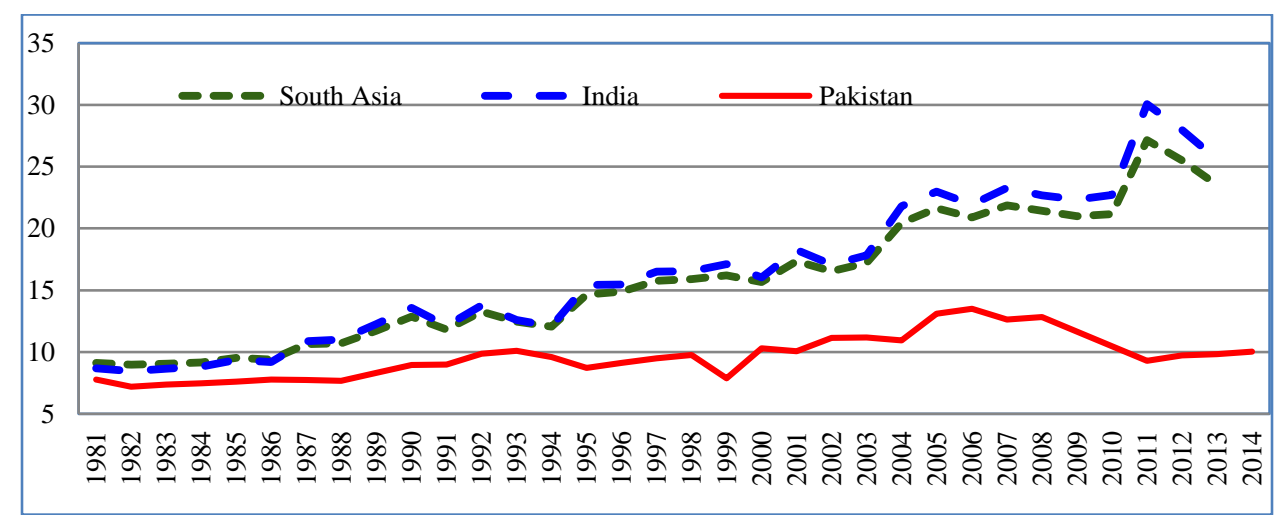

Source: Haver Analytics/World Development Indicators, World Bank 
Meanwhile, Table 2 reveals the R\&D expenditure allocated by Pakistan and a few select countries over time. While there are some breaks in the series and comparative data is not available beyond 2013, the numbers unambiguously reflect how Singapore and India have maintained a stable policy towards R\&D allocations, while China has consistently increased spending, reflecting an emphasis on boosting innovation and S\&T.

Table 2: R\&D expenditure percent of GDP

\begin{tabular}{lcccccccccccccccc}
\hline Country & 1999 & 2000 & 2001 & 2002 & 2003 & 2004 & 2005 & 2006 & 2007 & 2008 & 2009 & 2010 & 2011 & 2012 & 2013 \\
\hline China & 0.75 & 0.90 & 0.95 & 1.06 & 1.13 & 1.22 & 1.32 & 1.38 & 1.38 & 1.46 & 1.68 & 1.73 & 1.79 & 1.93 & 2.01 \\
India & 0.71 & 0.74 & 0.72 & 0.71 & 0.71 & 0.74 & 0.81 & 0.80 & 0.79 & 0.84 & 0.82 & 0.80 & 0.82 & n.a & n.a \\
Pakistan & 0.12 & 0.13 & 0.17 & 0.22 & n.a & n.a & 0.44 & n.a & 0.63 & n.a & 0.45 & n.a & 0.33 & n.a & 0.29 \\
Singapore & 1.82 & 1.82 & 2.02 & 2.07 & 2.03 & 2.10 & 2.16 & 2.13 & 2.34 & 2.62 & 2.16 & 2.01 & 2.15 & 2.00 & n.a \\
\hline
\end{tabular}

Source: World Development Indicators

Pakistan's policy, however, appears to have reversed course somewhat since 2007, with R\&D expenditure on the decline as of the last reported value in 2013. This trend appears to contradict a core objective of the country's National Science, Technology and Innovation Policy 2012, prepared by the Ministry of Science and Technology (MoST), which envisioned expansion of R\&D expenditure to 1 percent of GDP by 2015 and 2 percent by 2020. The policy also recommends extension of tax holidays, rebates and other incentives - particularly for firms which can integrate into global production networks or those engaged in information and communications technology, high-tech manufacturing, and the renewable energy sector. However, a case can be made that breakthrough results from such proposed incentives have either yet to materialize, or have not been documented and brought forward effectively into public knowledge.

\section{Section II. Availability of Finance}

Turning our attention to finance, Pakistan has been outperformed by its peers in terms of domestic credit extended to the private sector (Figure 3). More worryingly, a downward trend has been observed for this indicator since 2008. By contrast, China, Singapore, India, and Bangladesh have all witnessed an increase in their credit to GDP ratio. 
Figure 3: Domestic credit to private sector (\% of GDP)

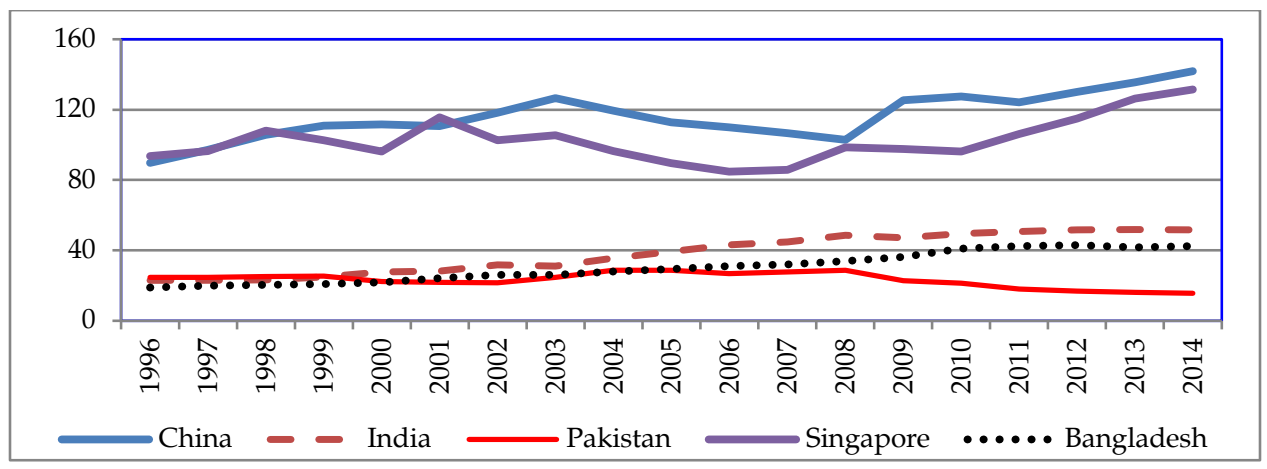

Source: World Development Indicators

Decomposing loans to private businesses in Pakistan down further, we find a severely lop-sided distribution which is skewed in favor of big corporations, while SMEs and agriculture sector are underserved. Table 3 indicates that, as of FY15, only 1.8 percent of total borrowers (including large corporations receiving loans in excess of Rs 10 million) were receiving over 80 percent of loans to private businesses. Furthermore, this situation has deteriorated over time, as evidenced by referring to FY05 figures.

Table 3: Distribution of loans to private businesses by size percent of total number of accounts and percent of total amount of loans

\begin{tabular}{lcccc}
\hline & \multicolumn{2}{c}{ FY05 } & \multicolumn{2}{c}{ FY15 } \\
\hline & $\begin{array}{c}\text { No. of } \\
\text { accounts }\end{array}$ & $\begin{array}{c}\text { Percent of total } \\
\text { loan amount }\end{array}$ & $\begin{array}{c}\text { No. of } \\
\text { accounts }\end{array}$ & $\begin{array}{c}\text { Percent of total } \\
\text { loan amount }\end{array}$ \\
Less than Rs 10 million & 99.2 & 27.2 & 98.2 & 18.7 \\
More than Rs 10 million & 0.8 & 72.8 & 1.8 & 81.3 \\
\hline
\end{tabular}

Source: State Bank of Pakistan

Foreign direct investment can also give a boost to innovation. On the one hand, it involves an injection of capital and financing; secondly, inflows are typically accompanied by technology and expertise transfer from foreign to local firms. Here, too, Pakistan has some catching up to do compared to its peers, seen in light of net inflows of FDI over the 2010-2014 period (Figure 4). The good news is that FDI inflows for Pakistan posted a modest uptick during Jul-Apr FY16, amounting to US\$1,017 million, compared to US $\$ 965$ million in comparable period of the previous fiscal year. Inflows from China on account of China Pakistan Economic Corridor (CPEC), in particular, hold promise in the medium to long term. 
Figure 4: FDI, net inflows percent of GDP

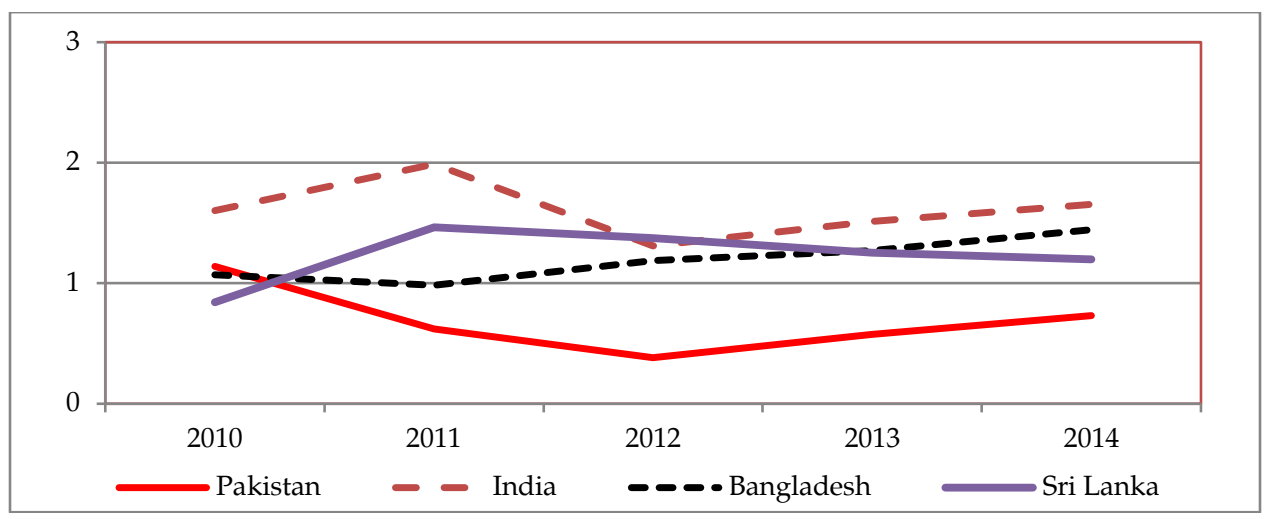

Source: World Development Indicators

Apart from bank credit and FDI, venture capital (VC) is also a viable source of funding for innovative startups. India has made notable gains in this avenue: in 2014, it received $\$ 5.2$ billion in venture capital funding, which was thrice the level of funding received in 2013.2 In 2015, these investments rose to $\$ 7.9$ billion. ${ }^{3}$ At least part of India's success with VC can be credited to policy making. Guidelines for venture capital funds were introduced in 1988, and consolidated in 1996 by Securities and Exchange Board of India (SEBI). More recently, the government of India launched an ambitious package to support growth of the VC industry and startup community. Proposals include setting up a $\$ 1.5$ billion fund for startups and providing tax breaks for the first three years in which they register profits.

By comparison, Pakistan's VC industry is still in its nascent stages. The country's startups were estimated to have raised US\$ 71.1 million in $2015 .{ }^{4}$ While this is dwarfed by the US\$ 7.9 billion raised in India, the trajectory holds promise nevertheless: VC funding for Pakistan had amounted to a mere US\$ 10.5 million only a year earlier, in 2014. From a regulatory perspective, the Securities and Exchange Commission of Pakistan (SECP) has introduced a number of related rules and regulations over the years. This includes, among others, the Private Equity and Venture Capital Fund Regulations 2008, the Private Funds Regulations 2015, the Non-Banking Finance Companies (NBFC) and Notified Entities Regulations 2008, which saw a number of subsequent amendments. An

\footnotetext{
${ }^{2}$ Ernst \& Young's Venture Capital Insights 4Q14 report

${ }^{3}$ KPMG and CB Insights' Venture Pulse Q42015 report

${ }^{4}$ Tech in Asia report, accessed from: https://www.techinasia.com/state-venture-capital-asia
} 
improved regulatory framework, consistent policies, and improved macroeconomic indicators and security situation could inspire further confidence in investors and see Pakistan's VC participation increase in the current year.

\section{Section III. SBP's financing initiatives}

Pakistan's central bank is playing an active role in facilitating the provision of financing for technology upgrades, innovation and balancing, modernization and replacement (BMR) through the following schemes:

1. Long Term Financing Facility (LTFF): provides funds for procurement of new local and imported machinery used in eligible export oriented projects;

2. Refinancing Facility for Modernization of SMEs: provides long term financing for local purchase/import of new machinery for BMR of existing SME units, setting up of new SME units and purchase of new generators up to $500 \mathrm{KVA}$;

3. Scheme for Financing Power Plants Using Renewable Energy: provides long term financing for imported and locally manufactured plants, machinery and equipment to be used in new power projects with capacity of up to $20 \mathrm{MW}$ using renewable energy sources; and

4. Financing Facility for Storage of Agricultural Produce (FFSAP): enables private firms to obtain refinancing for establishment/expansion of silos, warehouses and modern cold storage facilities.

Additional features and impact of these schemes, which are being executed in conjunction with participating banks and DFIs, is summarized in Table 4.

Table 4: SBP's long-term financing schemes

\begin{tabular}{|c|c|c|c|c|}
\hline Name of Scheme & $\begin{array}{l}\text { Year of } \\
\text { Introduction }\end{array}$ & $\begin{array}{l}\text { Maximum } \\
\text { Period }\end{array}$ & $\begin{array}{c}\text { Total amount } \\
\text { disbursed } \\
\text { (Billion Rs) }\end{array}$ & $\begin{array}{c}\text { Outstanding } \\
\text { amount } \\
\text { (Billion Rs) }\end{array}$ \\
\hline LTFF for plant \& machinery & $31-12-2007$ & 10 years & 100.7 & 39.800 \\
\hline $\begin{array}{l}\text { Refinancing facility for } \\
\text { modernization of SMEs }\end{array}$ & 02-09-2009 & 10 years & 0.3 & 0.090 \\
\hline $\begin{array}{l}\text { Scheme for financing power } \\
\text { plants using renewable energy }\end{array}$ & 01-12-2009 & 10 years & 0.2 & 0.173 \\
\hline FFSAP & $04-06-2010$ & 7 years & 4.0 & 1.900 \\
\hline
\end{tabular}

Source: SBP Development Finance Review, 2015 
In the domain of microfinance, SBP has launched the microfinance credit guarantee facility to reduce the risks against loans extended to microfinance providers by commercial banks. Further measures include introduction of regulations for Microfinance banks (MFBs) in 2001; creation of a microfinance credit information bureau (m-CIB) from 2009-2012; and high investment in the Institutional Strengthening Fund. The interest of microfinance clients were also safeguarded via measures like the Client Protection Initiative (CPI), executed in conjunction with the Pakistan Microfinance Network (PMN). ${ }^{5}$

SMEs are also an underserved segment in terms of financing from commercial banks. An important factor in this regard is the high infection ratio prevalent among SMEs, compared to other borrowers (Table 5).

Table 5: Composition of Banks' Advances and Infection ratio percent

\begin{tabular}{lcccccccc}
\hline & CY08 & CY09 & CY10 & CY11 & CY12 & CY13 & CY14 & CY15 \\
\hline Banks' Advances & & & & & & & & \\
Corporate & 63.16 & 61.86 & 62.72 & 64.58 & 65.77 & 66.89 & 66.72 & 66.30 \\
SMEs & 11.75 & 10.42 & 9.34 & 8.11 & 6.59 & 6.30 & 6.07 & 5.97 \\
Agriculture & 4.87 & 4.69 & 4.56 & 4.72 & 4.85 & 5.12 & 5.36 & 5.46 \\
Consumer financing & 10.41 & 8.05 & 6.99 & 6.47 & 5.96 & 6.06 & 5.96 & 6.30 \\
Commodity & 7.37 & 12.54 & 12.31 & 11.68 & 12.22 & 10.63 & 11.13 & 11.15 \\
financing & & & & & & & & \\
Other & 2.45 & 2.46 & 4.08 & 4.44 & 4.60 & 4.99 & 4.75 & 4.82 \\
& & & & & & & & \\
Infection Ratio & & & & & & & & \\
Corporate & 8.9 & 12.6 & 15.4 & 17.1 & 15.2 & 13.4 & 13.0 & 12.3 \\
SMEs & 15.8 & 22.1 & 28.0 & 31.4 & 34.6 & 32.3 & 30.5 & 26.1 \\
Agriculture & 15.8 & 16.5 & 17.9 & 19.3 & 14.5 & 14.0 & 12.4 & 13.0 \\
Consumer financing & 6.9 & 12.2 & 16.9 & 18.6 & 17.5 & 13.6 & 11.6 & 8.7 \\
Commodity & 1.4 & 1.1 & 1.3 & 1.1 & 1.1 & 1.1 & 1.0 & 1.2 \\
financing & & & & & & & & \\
Others & n.a & n.a & 15.4 & 13.3 & 10.8 & 8.9 & 7.1 & 8.6 \\
Total & 10.5 & 12.6 & 14.7 & 16.2 & 14.5 & 13.0 & 12.3 & 11.4 \\
\hline
\end{tabular}

Source: State Bank of Pakistan

\footnotetext{
${ }^{5}$ CPI was a 3-year project funded under SBP's Financial Inclusion Program from January 2013 to March 2015. It consisted of two components: a) pricing transparency, to promote responsible and transparent pricing practices among microfinance practitioners (MFPs); and b) client protection monitoring, via third party assessments of PMN's member MFPs, to ensure compliance with global benchmarks
} 
In this backdrop, the central bank has taken following steps specifically for provision of financing for SMEs: assignment of targets to commercial banks, with the aim of extending nearly Rs 100 billion in SME financing in the calendar year 20166; formulation of a regulatory framework encompassing SME financing, revised in 2013; establishment of e-Credit Information Bureau; and ongoing work for creation of a secure transaction registry for extending small-scale loans.

Furthermore, the Export Finance Scheme (EFS) contains some special measures for SMEs who export significant portion of their products, such as the requirement that banks apportion a minimum 10 percent of their EFS limit to such enterprises. In general, the EFS scheme, introduced in 1973, provides short term financing facility for exports of a wide variety of manufacturing goods (especially value-added products). ${ }^{7}$ As per EFS Part-I, which is a transaction based facility, commercial banks provide export finance to exporters against firms' export orders, contracts or letters of credit. This facility has a tenor of up to 180 days, with a rollover option for further 90 days subject to fulfillment of certain conditions. Meanwhile, EFS Part-II is a performance based facility, whereby the entitlement of an exporter for revolving export finance limit is equal to 50 percent of export proceeds realized through export of eligible commodities in the preceding financial year. As of June 30, 2015, outstanding financing under EFS amounted to Rs 191.1 billion.

Meanwhile, given the importance of the agriculture sector, Prudential Regulations for Agriculture Financing have been introduced and revised as necessary by SBP to ensure that farmers have due access to financing. A Livestock Insurance Scheme also offers livestock owners a buffer against hazards and disease-induced losses, while the Crop Loan Insurance Scheme has also been enhanced. Progress was also made during FY15 to develop Warehouse Receipt Financing and credit guarantee scheme for small and marginalized farmers. SBP has also facilitated trainings featuring international experts to train local participants regarding innovations and global best practices in the domain of agriculture financing.

Women also represent an underserved segment of the economy, though gains have been made in the past few years. SBP's Access to

\footnotetext{
${ }^{6}$ Outstanding SME financing was Rs 305 billion as on $31^{\text {st }}$ December 2015, according to SBP's Quarterly SME Financing Review (December 2015)

${ }^{7}$ Some basic and primary commodities/raw materials, mentioned in negative list, are excluded from EFS
} 
Finance (A2F) 2015 survey reveals that 43 percent of Pakistani females are financially included as of 2015, compared to 33 percent in 2008. Narrowing down further to the banked segment, 11 percent of women are classified as banked, compared to 4 percent in $2008 .{ }^{8}$ The A2F 2015 findings suggest that lower participation by females in the labor force and economic life compared to men is an important determinant of financial exclusion; those classified as housewives were not significantly less informed about financial services. Initiatives like WomenX, a pilot program which provides business education and support services to female SME owners, as well as preferential treatment for women by organizations like the Pakistan Poverty Alleviation Fund, are either directly addressing women's needs for financing, or indirectly facilitating inclusion by involving women in economic activities to a greater degree.

Other notable steps taken by SBP to promote financial inclusion in the country include:

- Adoption of Branchless Banking Regulations in 2008

- Execution of nationwide Financial Literacy Program in 2012

- Development work for an Inclusion, Stability, Integrity and Protection (I-SIP) methodology in 2014

- Provision of support in setting up the Prime Minister's Youth Business Loans scheme, including training workshops for participating banks.

However, the overall financial inclusion scenario remains challenging. Recognizing the need for further measures, SBP introduced the National Financial Inclusion Strategy (NFIS) in 2015. The NFIS provides a five-year action plan to guide public and private actors in the drive to increase financial inclusion. It covers priority areas such as branchless banking, SME finance and infrastructure, microfinance, rural, and agriculture finance, housing finance, Islamic finance, digital payment systems, consumer protection and financial literacy, and insurance and pensions. The Ministry of Finance and the Securities and Exchange Commission of Pakistan are among key stakeholders taking leadership role along with SBP in implementation of the strategy.

\footnotetext{
${ }^{8}$ Banked individuals are those who (a) are owners or users of bank accounts at any formal institution (except the National Savings Center), and/or (b) are owners or users of mobile accounts (as of 2015; did not exist in 2008)
} 
The NFIS vision is for individuals and firms in Pakistan to have access and use a range of quality payments, savings, credit and insurance services which meet their needs with dignity and fairness. The link with innovation and S\&T is several-fold: the strategy encourages the introduction of new products and services which address the needs of the under-served; it promotes development and expansion of innovative channels, such as branch-less banking and digital transaction accounts; by including marginalized segments, like women and micro, small and medium enterprises (MSMEs), increasingly into the fold, it opens up opportunities to engage in S\&T activity which was previously limited on account of lack of financial access or inadequate funding.

\section{Section IV. Role of innovation in expanding financial access}

Technology itself is accelerating the pace of financial inclusion. Thus, digital technologies and mobile financial services can, on the one hand, lead to an increase in financial inclusion. On the other hand, this increased access to finance can further open new avenues for various actors - MSMEs and entrepreneurs in particular - to avail funds for the launch of technology based ventures, or modernization of existing businesses.

The NFIS recommends the use of technology and innovative risk assessment models in serving the needs of Pakistan's MSMEs. By 2020, it targets an increase in SME lending as a proportion of total bank credit to the private sector to 15 percent, from 7 percent originally. Meanwhile, the overarching NFIS target is to increase access to formal accounts from 10.3 percent $t^{9}$ of adults with a transactions or other type of formal account to 50 percent by 2020 .

Mobile technology in particular holds great promise. On average, nine out of ten households in the country have access to a mobile phone and SIM card. According to the World Bank Global Findex 2014 database, 5.8 percent of Pakistani adults had mobile accounts, compared to the South Asian average of 2.6 percent. Moreover, a similar pattern was observed in rural areas, which is important in the context of universal financial inclusion.

Encouraged by the Branchless Banking Regulation Act and subsequent regulatory initiatives taken by SBP, Pakistan has become one of the fastest growing markets for branchless banking in the world, with Tameer MFBs 'EasyPaisa' providing a widely heralded success story.

\footnotetext{
${ }^{9}$ Financial Inclusion Insights 2014
} 
Complimentary steps taken by the central bank include the execution of National Financial Literacy Program and improvement in payments and settlement system.

\section{Figure 5: Periodic trend of G2P disbursements}

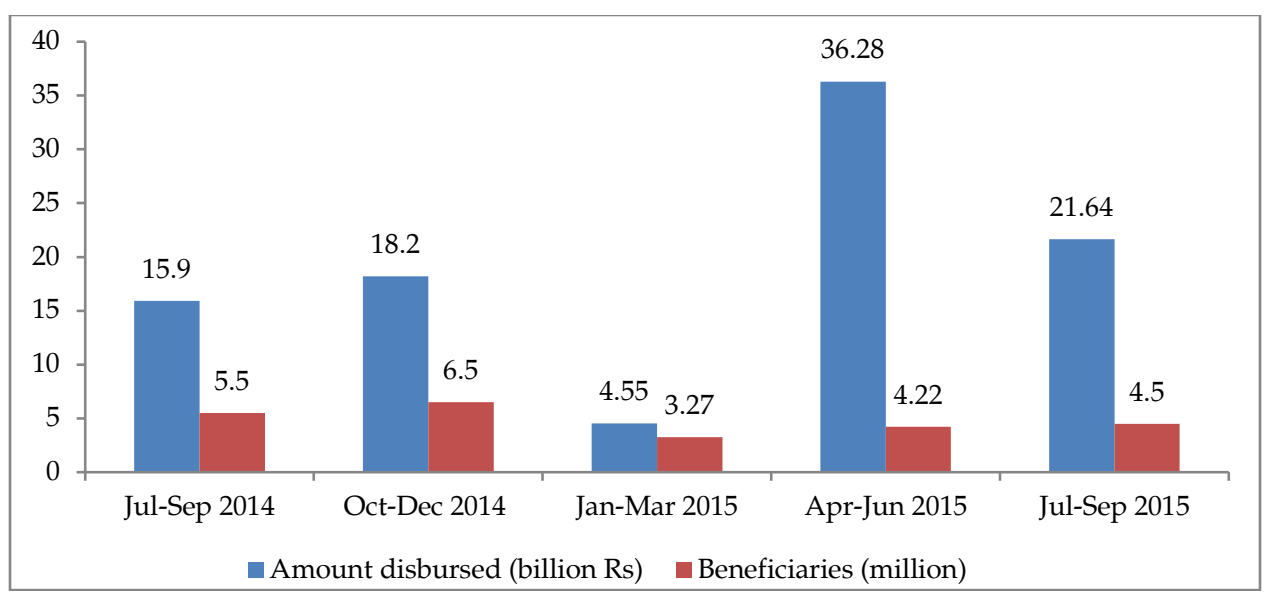

Source: SBP Quarterly Branchless Banking Newsletter, Issue 17, Jul-Sep 2015

The government is also keen on promoting branchless banking, as evidenced by growing digitization of Government-to-Person (G2P) payments, including efforts to digitize payments made to Benazir Income Support Program (BISP) beneficiaries. Figure 5 reveals the periodic trend in G2P disbursements, facilitated by branchless banking. An amount of Rs 21.6 billion was disbursed to 4.5 million beneficiaries in Jul-Sep FY15, comprising BISP (Rs 15.5 billion to 3.5 million beneficiaries), IDP (Rs 5.4 billion to 141,080 beneficiaries), EOBI (Rs 388 million to 68,369 beneficiaries) and others (Rs 256.9 million to 720,804 beneficiaries). ${ }^{10}$

Furthermore, the Pakistan Telecommunication Authority (PTA), National Database and Registration Authority and 1Link are also playing an active role in developing the infrastructure. Recent measures include SBP and PTA's efforts to introduce interoperability among branchless banks, and the central bank's development of an online application to monitor branchless activity and prevent any misuse of funds. SBP and 1Link also inaugurated the first domestic payment scheme, PayPak, in April 2016, with the new card offering the benefit of low cost, ease of affordability and security to ordinary citizens.

${ }^{10}$ SBP Quarterly Branchless Banking Newsletter, Issue 17 (Jul-Sep 2015) 
Pakistan has made some gains in expanding the geographical outreach of financial services, even though it has been outpaced on these dimensions by Bangladesh and India (Figures 6 and 7). ATMs, in particular, represent an instant, safe and convenient way to access funds. Meanwhile, expanded access opens up further possibilities of innovation, as evidenced by global trials of card-less ATMs which employ smartphones instead of debit cards.

Figure 6: Commercial bank branches per 100,000 adults

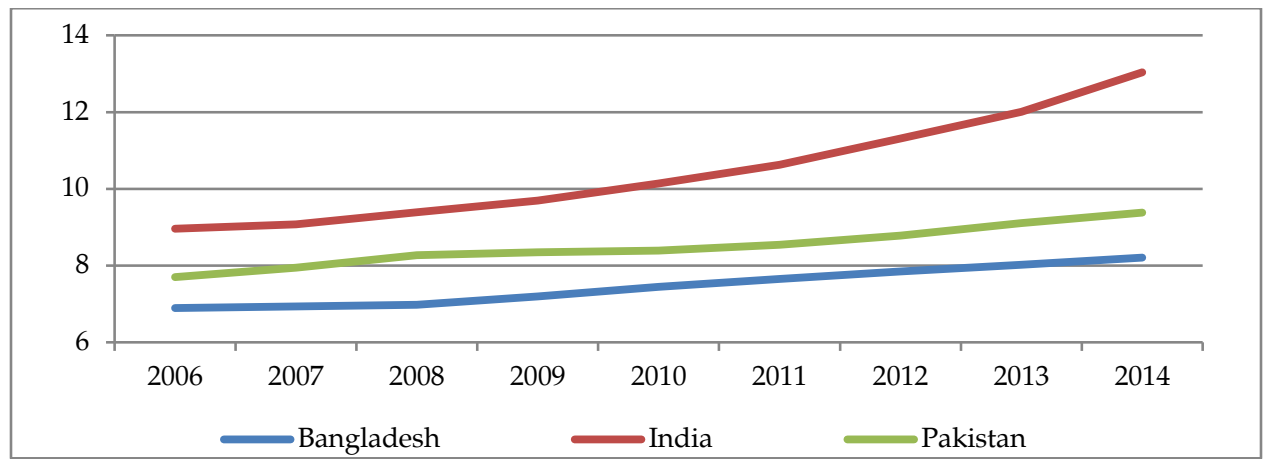

Source: IMF Financial Access Surveys

Figure 7: ATMs per 100, 000 adults

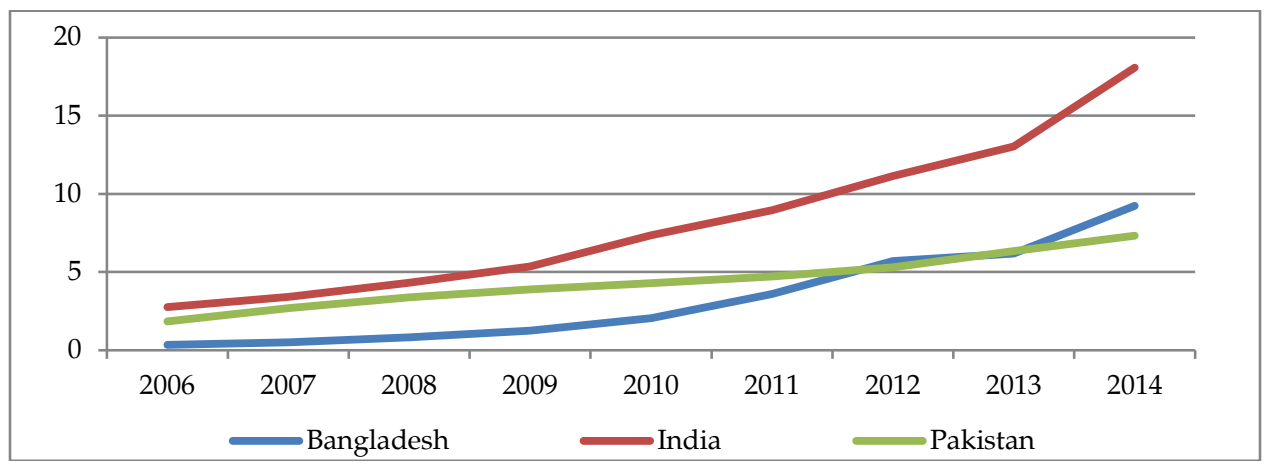

Source: IMF Financial Access Surveys

Improved access has, in turn, resulted in a noteworthy shift towards modes of electronic banking. Specifically, FY14 saw the number of transactions using E-banking overtake the number of transactions via traditional, paper-based instruments (Table 5). 
Table 5: Number of Transactions millions

\begin{tabular}{lccccc}
\hline & FY11 & FY12 & FY13 & FY14 & FY15 \\
\hline Paper based instruments & 343.8 & 357 & 359 & 362 & 362 \\
Electronic banking & 234.9 & 277.4 & 320.5 & 403.7 & 469.1 \\
Real time online banking & 74.4 & 83.1 & 89.1 & 98.5 & 113.8 \\
ATMs & 137.7 & 166.2 & 199.8 & 258.5 & 300.3 \\
Point of sale terminals & 14.3 & 17.5 & 17.3 & 24.3 & 32.1 \\
Internet banking & 4.4 & 6.9 & 9.6 & 15.6 & 16 \\
Mobile banking & 3.3 & 3.1 & 4.2 & 6.2 & 6.1 \\
Call center & 0.8 & 0.7 & 0.6 & 0.7 & 0.8 \\
\hline
\end{tabular}

Source: SBP Payment Systems Review, FY15

In addition, another project leveraging innovation being implemented by SBP is the Financial Innovation Challenge Fund (FICF). This fund, with provision of grants worth GBP 10 million (sponsored by UK Aid), consists of several thematic rounds; themes identified to date include 'Financially Inclusive G2P Payments', 'Innovative Rural and Agriculture Finance in Pakistan', and 'Promoting Excellence in Islamic Finance'. The fund provides seed capital and envisages the scaling up of new ventures with support from donors and private sector agents.

Finally, SBP has set up three Centers of Excellence in Islamic Finance (CEIFs) in order to promote quality research and development and a knowledge environment which promotes innovation. The CEIFs have been established at IBA (Karachi), LUMS (Lahore), and Institute of Management Sciences (Peshawar).

\section{Conclusion}

We have seen that countries which prioritize S\&T and innovation, as reflected by indicators like $R \& D$ expenditure, reap the benefits in terms of economic growth and development. In addition, availability of bank financing tends to spur innovative activities. Pakistan has lagged behind in this regard compared to countries like India and Singapore, and is paying the price as a result. We have also touched upon the venture capital industry, and how India has tapped into this alternative source of funding for innovative enterprises with some degree of success.

SBP has taken a number of initiatives to make financing available, especially for underserved segments and those entities which require funds to upgrade their processes and technology resources. These 
measures include promoting access to finance for SMEs, agriculture sector, and export-oriented firms, for the establishment of new units, import of machinery and expansion/BMR of existing facilities. The central bank has also provided impetus for spread of innovative banking models, like branchless banking, under the umbrella of ambitious strategies targeting nation-wide financial inclusion and digitization of processes. Collectively, these measures constitute a regulatory framework which supports S\&T and innovation in the country. 


\section{References}

Ayyagari, M., Demirgüç-Kunt, A., \& Maksimovic, V. (2012). Firm innovation in emerging markets: the role of finance, governance, and competition. Journal of Financial and Quantitative Analysis, Vol. 46(06), pp. 1545-1580.

Chandrasekhar, K. B. (2000). Report of KB Chandrasekhar Committee on Venture Capital. Delhi: Securities and Investment Board of India. Retrieved from http://www.sebi.gov.in/commreport/venrepcover.html

Cornell University, INSEAD, and WIPO (2015). The Global Innovation Index 2015: Effective Innovation Policies for Development, Fontainebleau, Ithaca, and Geneva. Retrieved from https://www.globalinnovationindex.org/content/page/gii-fullreport-2015/

Dabla-Norris, E., Kersting, E., \& Verdier, G. (2010). Firm productivity, innovation and financial development (IMF Working Paper No. 10/49). Retrieved from https://www.imf.org/external/pubs/ft/wp/2010/wp1049.pdf

Demirguc-Kunt, A., Klapper, L., Singer, D. \& Van Oudheusden, P. (2014). The Global Findex Database 2014. Measuring Financial Inclusion Around the World. World Bank Working Paper No. 7255. Retrieved from http://www.worldbank.org/en/programs/globalfindex

Ernst \& Young (2015). Venture Capital Insights - 4Q14. Retrieved from http://www.ey.com/Publication/vwLUAssets/Venture_Capital _Insights_4Q14_-_January_2015/\$FILE/ey-venture-capitalinsights-4Q14.pdf

KPMG and CB Insights (2016). Venture Pulse Q42015.Retrieved from https://www.kpmg.com/NL/nl/IssuesAndInsights/ArticlesPub lications/Documents/PDF/Corporate-Finance/Venture-PulseQ4-2015.pdf

Ministry of Science and Technology, Government of Pakistan (2012). National Science, Technology and Innovation 2012 Policy. Retrieved from http://most.comsatshosting.com/\%5CPolicies\%5CNational Science, Technology and Innovation Policy 2012.pdf 
State Bank of Pakistan (2012) Export Finance Scheme. Retrieved from http://www.sbp.org.pk/incentives/BookGuidlines-EFS.pdf

State Bank of Pakistan (2014). Handbook on Long Term Financing Facilities of State Bank of Pakistan. Retrieved from http://www.sbp.org.pk/incentives/ltfeop/FinancingSchemes.pdf

State Bank of Pakistan (2015). Access to Finance Survey 2015. Retrieved from https://www.a2f2015.com/

State Bank of Pakistan (2015). Annual Performance Review 2014-15. Retrieved from http://www.sbp.org.pk/sbp_bsc/apr/Perf-14-15/perfor15.htm 